\title{
FANCI wt Allele
}

National Cancer Institute

\section{Source}

National Cancer Institute. FANCI wt Allele. NCI Thesaurus. Code C92475.

Human FANCI wild-type allele is located in the vicinity of $15 q 26.1$ and is approximately 73 $\mathrm{kb}$ in length. This allele, which encodes Fanconi anemia group I protein, is involved in the modulation of DNA repair. Mutation of the gene is associated with Fanconi anemia complementation group I. 